\title{
VÝMĚNA PUBLIKACÍ KNIHOVNY NÁRODNÍHO MUZEA V LETECH 2011-2020
}

\author{
Jarmila Kučerová (Praha)
}

The International Exchange of Publications of the National Museum Library in 2011-2020

\begin{abstract}
The international exchange of publications has a long tradition in the National Museum. It is an important source of foreign scientific literature as well as a very useful way of distributing publications published by the National Museum and thus presenting its scientific results. The paper describes the situation and changes in this area in the period of 2011-2020. It summarises the main external influences and tendencies. It compares acquisitions by purchase and exchange. It describes the current goals of the international exchange of publications in the National Museum Library.
\end{abstract}

Keywords: acquisition - international exchange of publications - National Museum Library (Prague)

\section{Úvod}

Mezinárodní výměna publikací má v Národním muzeu (dále NM) dlouholetou tradici: používá se již od jeho vzniku a je cenným akvizičním zdrojem odborné literatury dodnes. Vedle výměny se zahraničím probíhá $\mathrm{v}$ menším rozsahu i výměna domácí. Tento prríspěvek sleduje období výměny publikací Knihovny Národního muzea (dále KNM) od roku 2011 do roku 2020, a navazuje tak na článek autorky týkající se období 1990-2010¹ a její další práce, dále na publikace Jaroslava Vrchotky ${ }^{2}$ a Tat'jány Spunarové, ${ }^{3}$ které pokrývají období předchozí.

\section{Mezinárodní výměna publikací v Národním muzeu}

Národní muzeum je vědeckou institucí a jeho publikační činnost, jak periodická, tak monografická, je poměrně rozsáhlá - má tedy bohatou nabídku publikací na výměnu. Na jedné straně slouží výměna publikací k získávání odborné literatury, na straně druhé je vhodným způsobem rozšiřování vlastní vydávané literatury, která je výsledkem vědecké práce a je často úzce specializovaná.

Mezinárodní výměnu publikací v současnosti podporují především tyto zákony, kterými se naše republika připojila k mezinárodním úmluvám: je to Úmluva o mezinárodní výměně publikací (č. 12/1965 Sb.), dále Dohoda o dovozu vzdèlávacích, védeckých a kulturních materiálů (̌c. 102/1998 Sb.) a Protokol k Dohodě o dovozu vzdělávacích, vědeckých a kulturních materiálů (̌̌. 103/1998 Sb.).

Knihovna NM má nejrozsáhlejší výměnnou sít' v České republice a výměna publikací je jejím hlavním zdrojem odborné literatury. Kromě Knihovny NM se výměnou publikací v Národním muzeu zabývá v menším rozsahu také zoologické oddělení a entomologické oddělení Přírodovědeckého muzea NM, Knihovna Náprstkova muzea a České muzeum hudby.

Oddělení mezinárodní výměny publikací KNM (KNM7) získává pro KNM a odborná oddělení NM odborné publikace koupí, darem a především výměnou. Čtyři knihovnice vykonávají akvizici, vstupní zpracování publikací, vedení lokálních katalogů, správu fondu výměny a expedici publikací. Od r. 2017 se toto oddělení stará i o nákup elektronických informačních zdrojů v rámci projektu CzechELib: ve spolupráci s oddělením služeb KNM (KNM6) zpřístupňuje v současnosti celkem 8 licencovaných databází pro vědeckou práci NM.

Kumulace více akvizičních zdrojů v jednom oddělení je výhodná: pokud je to možné, snažíme se publikace získat výměnou za naše tituly. Není to vedeno jen snahou o úsporu, ale výměna pomáhá i tam, kde jde o obtížně dostupnou literaturu, která není běžně na trhu.

\section{Hlavní změny v letech 2011-2020}

Zatímco období 1990-2010 ovlivňovaly především společenské a ekonomické změny, v následujících letech 20112020 se výrazněji projevují změny ve vydavatelské oblasti: zejména vydávání elektronických publikací, nárůst fulltextových databází a nově také elektronické publikování v režimu „Open Access“. Nadále probíhají organizační změny $\mathrm{v}$ institucích a jejich knihovnách.

Je překvapivé, že změny formátů a režimů publikování zatím nezpůsobují výrazný pokles objemu výměny, ani nejsou zásadním důvodem $\mathrm{k}$ jejímu ukončení, jak by se dalo předpokládat.

\footnotetext{
${ }^{1}$ KUČEROVÁ 2011 a k dalšímu studiu rovněž KUČEROVÁ 1998, 1999, 2005, 2008 a 2012.

2 VRCHOTKA 1956, 1967.

3 SPUNAROVÁ 1974, 1976, 1990.
} 
V KNM tak zatím dochází k zastavení výměny ze dvou hlavních a téměř rovnocenných důvodů: 1) důvody organizační (reorganizace institucí, slučování knihoven, nedostatek místa, možná i pracovníků...) a 2) rušení neaktivních výměn (výměnný partner nic neposílá a nereaguje - my ho vyřazujeme $\mathrm{z}$ adresáře). Ukončení vydávání periodik v tištěné podobě je důvodem ke zrušení výměny až na třetím místě, a to pouze tam, kde nejsou v nabídce výměny žádné tištěné publikace (monografie, sborníky, katalogy sbírek, ...).

K obdobným poznatkům dochází také Christian Schmidt, ${ }^{4}$ který uskutečnil rozsáhlý průzkum na vzorku 69 vědeckých knihoven v Německu: elektronické publikování samozřejmě přináší změny, ale není jediným a primárním faktorem, který by výměnu publikací ovlivňoval - významnou roli hraje i snižování rozpočtu a nedostatek pracovníků. Při přechodu na elektronické publikování jsou pak online periodika dostupná bud' zdarma (režim „Open Access“), nebo koupí: avšak zajištění přístupu k placeným online periodikům ze strany výměnného partnera je spíše výjimkou.

\section{Obsah a rozsah výměny}

\section{Publikace na výměnu}

Knihovna NM rozesílá převážně publikace vydané Národním muzeem, v menší míre duplikáty a pouze výjimečně kupované tituly.

Základem výměny publikací jsou periodické tituly Národního muzea, které mají většinou dlouhou tradici, třebaže v průběhu let došlo u některých ke změně názvu, zaměření, př́íp. i struktury.

Základ výměnného fondu tvoří:

- Časopis Národního muzea. Ǩada historická

- Journal of the National Museum (Prague), Natural History Series

- Acta Musei Nationalis Pragae - Historia (dř́ve: Sborník Národního muzea v Praze, řada A-Historie)

- Fossil Imprint (dř́ve: Sborník Národního muzea v Praze, řada B-Přrrodní védy)

- Acta Musei Nationalis Pragae - Historia litterarum (dřive: Sborník Národního muzea v Praze, řada CLiterární historie)

- Numismatické listy

- Muzeum: Muzejní a vlastivédná práce

- Fontes Archaeologici Pragenses

- Bulletin Mineralogie Petrologie (dř́ve: Bulletin mineralogicko-petrologického oddělení Národního muzea $v$ Praze)

Většina periodik NM je sice dostupná zdarma v online verzi na webu NM, přsesto je nadále zájem i o jejich tištěnou verzi.

Neperiodické publikace Národního muzea jsou také $\mathrm{k}$ dispozici na výměnu, ale v menším počtu výtisků než periodika, takže je většinou nelze rozesílat hromadně, ale pouze výběrově - formou individuálních zásilek. Jde o vědecké monografie, katalogy sbírek, katalogy výstav, populárně-naučné a metodologické publikace.
Počet výměnných partnerů KNM v letech 2011-2020 (porovnání s r. 2010)

\begin{tabular}{|c|c|c|c|}
\hline rok & ČR & zahr. & celkem \\
\hline 2010 & 57 & 809 & 866 \\
\hline 2011 & 60 & 794 & 854 \\
\hline 2012 & 63 & 783 & 846 \\
\hline 2013 & 65 & 784 & 849 \\
\hline 2014 & 70 & 782 & 852 \\
\hline 2015 & 71 & 773 & 844 \\
\hline 2016 & 73 & 756 & 829 \\
\hline 2017 & 76 & 743 & 819 \\
\hline 2018 & 75 & 740 & 815 \\
\hline 2019 & 76 & 722 & 798 \\
\hline 2020 & 76 & 716 & 792 \\
\hline
\end{tabular}

Obr. 1. Počet výměnných partnerů v letech 2011-2020 a porovnání s rokem 2010.

Přehled zemí s největším počtem výměnných partnerů v roce 2010 a 2020

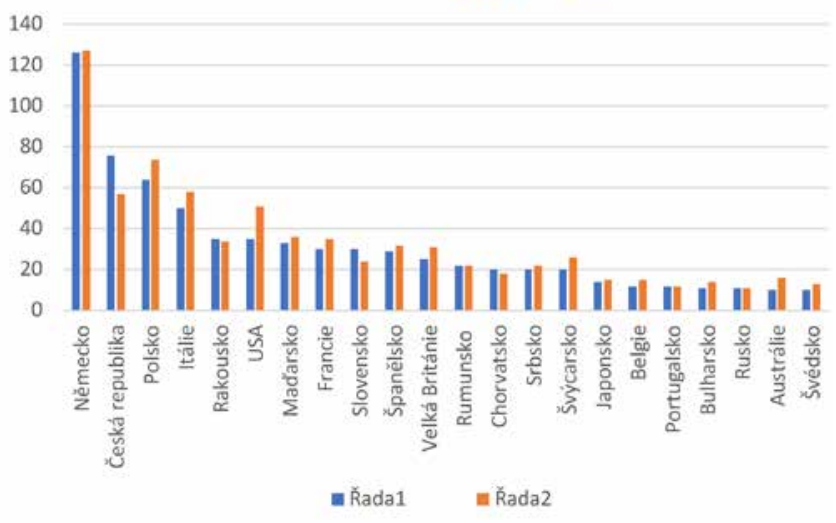

Obr. 2. Přehled zemí s největším počtem výměnných partnerů porovnání let 2010 a 2020.

\section{Sít' výměnných partnerů}

Sít' výměnných partnerů KNM ke konci roku 2020 tvoří 792 institucí v 58 zemích, z toho 76 z ČR a 716 ze zahraničí. Oproti roku 2010 sice došlo v tomto desetiletí k poklesu zahraničních partnerů o 93 institucí, ale je to důsledkem přirozeného vývoje. Neusilujeme o pouhé navyšování počtu, ale o udržování takových výměn, které jsou přínosné pro naši akvizici odborné literatury. Stále jde o velmi rozsáhlou výměnnou sít'. Dlouhodobě máme největší počet výměnných partnerů (nad 25 institucí) v těchto státech: Německo, Česká republika, Polsko, Itálie, Rakousko, USA, Mad'arsko, Francie, Slovensko, Španělsko a Velká Británie. Neméně významné jsou i další státy, třebaže někdy zastoupené jen několika či jednou institucí. Potěšující je i nárůst zájmu o výměnu ze strany institucí v ČR - od r. 2010 se jejich počet zvýšil o 19 institucí. 


\begin{tabular}{|c|c|l|}
\hline \multicolumn{2}{|l|}{ Důvody ukončení výměny za posledních 5 let } \\
\hline $\begin{array}{l}\text { pořadí dle } \\
\text { četnosti } \\
\text { sestupně }\end{array}$ & $\begin{array}{l}\text { počet } \\
\text { ukončených } \\
\text { výměn }\end{array}$ & důvod \\
\hline 1. & 28 & $\begin{array}{l}\text { my je vyřazujeme } \\
\text { z adresáře, protože nic } \\
\text { neposílají a nereagují }\end{array}$ \\
\hline 2. & 27 & $\begin{array}{l}\text { oni ruší výměnu - } \\
\text { nejčastěji z důvodu } \\
\text { reorganizace (slučování } \\
\text { knihoven...), nedostatku } \\
\text { prostoru, změna zaměření }\end{array}$ \\
\hline 3. & 12 & $\begin{array}{l}\text { oni ruší výměnu z důvodu } \\
\text { přechodu na online verze } \\
\text { periodik }\end{array}$ \\
\hline
\end{tabular}

Obr. 3. Důvody ukončení výměny za posledních 5 let. posíláme převážně periodika a monografickou řadu Fontes Archaeologici Pragenses, avšak získáváme nejen periodika, ale i velké množství knih. Mírné výkyvy v průběhu let nejsou negativním jevem: jsou zpơsobeny jednak možnostmi výměnných partnerů, jednak usměrňováním výměny z naší strany - pomocí průběžné obsahové revize dodávaných titulů a postupných uvážlivých změn. Meziroční poklesy bývají většinou vyrovnány v následujícím roce.

Poslední rok tohoto období, rok 2020, byl poznamenán pandemií koronaviru COVID-19 sice dosti negativně, ale zároveň se projevila solidarita a vstř́ícnost. Kvůli práci knihovníků z domova byla snížena kapacita na expedici publikací na obou stranách, omezení poštovní přepravy přineslo problémy s rozesíláním: často se měnící poštovní pravidla jednotlivých zemí vyžadující neustálé sledování, kam lze posílat, vracení zásilek. Na druhé straně vždy velice potěšil vděk knihovníků za dodané publikace a povzbudivá slova s přáním

\begin{tabular}{|c|c|c|c|c|}
\hline \multicolumn{5}{|c|}{ Mezinárodní výměna publikací KNM v letech 2011-2020 (porovnání s r. 2010) } \\
\hline rok & $\begin{array}{l}\text { počet odeslaných } \\
\text { publikací (ks) }\end{array}$ & $\begin{array}{l}\text { hodnota odeslaných } \\
\text { publikací (Kč) }\end{array}$ & $\begin{array}{l}\text { počet získaných } \\
\text { publikací (ks) }\end{array}$ & $\begin{array}{c}\text { hodnota získaných publikací } \\
\text { (Ǩ̌) }\end{array}$ \\
\hline 2010 & 3143 & 239517,00 & 2346 & 1060830,00 \\
\hline 2011 & 4165 & 539514,00 & 2744 & 1166750,00 \\
\hline 2012 & 3963 & 483720,00 & 2179 & 1253945,00 \\
\hline 2013 & 3775 & 440652,00 & 1875 & 872951,00 \\
\hline 2014 & 2616 & 455807,00 & 1425 & 1037431,00 \\
\hline 2015 & 3231 & 591656,00 & 1532 & 1026540,00 \\
\hline 2016 & 3531 & 536355,00 & 1884 & 1447065,00 \\
\hline 2017 & 3243 & 506596,00 & 1726 & 1135589,00 \\
\hline 2018 & 2757 & 272332,00 & 1751 & 1163014,00 \\
\hline 2019 & 2816 & 350563,00 & 1848 & 1234158,00 \\
\hline 2020 & 2303 & 329850,00 & 1409 & 821684,00 \\
\hline
\end{tabular}

Poznámka: jednotkou je zde kniha nebo číslo časopisu

Obr. 4. Přehled odeslaných a získaných publikací a porovnání s rokem 2010.

Určitým dokladem, že u výměny publikací nejde jen o tradici, jsou údaje o našich významných partnerech: např. Naturhistorisches Museum Wien má cca 1190 výměnných partnerů, Senckenbergische Naturforschende Gesellschaft (Frankfurt am Main) udržuje výměnné kontakty s více než 1860 institucemi v 97 zemích, Fundação Biblioteca Nacional (Rio de Janeiro) zmiňuje více než 700 knihoven, se kterými spolupracuje ve výměně. Dlouhodobá spolupráce je typická nejen pro instituce, ale i jejich knihovníky. ${ }^{5}$

\section{Publikace získané výměnou}

Porovnání vyměňovaných publikací potvrzuje výhodnost výměny pro naši instituci. Ohledně poměru počtu a hodnoty vyměňovaných publikací je třeba připomenout, že

\section{Zahraniční odborná periodika KNM - poměr nákupu (26 \%) a výměny (74\%)}

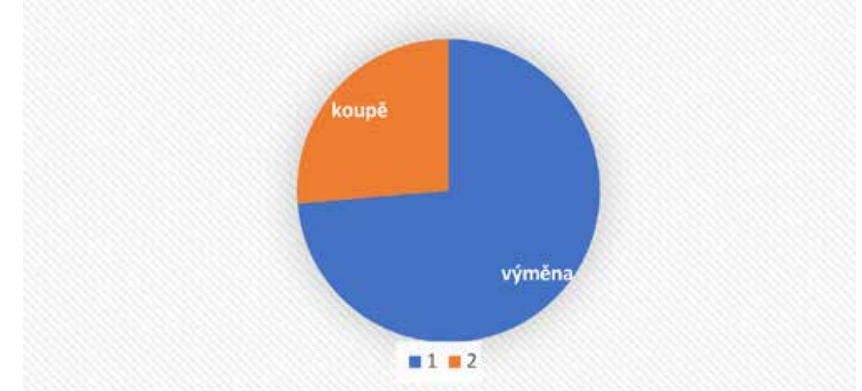

Obr. 5. Porovnání počtu titulů zahraničních periodik získávaných výměnou a koupí.

\footnotetext{
5 Věrnost profesi knihovníka ve výměně dokládají dopisy, které jsme obdrželi od kolegů při jejich odchodu do důchodu: např. po 35 letech (University Library at Sofia University „St. Kliment Ohridski“), po 36 letech (Bibliotheques et Archives des Musées Nationaux, Paris), po 37 letech (Meise Botanic Garden, Meise), a dokonce po 42 letech (Universiteitsbibliotheek KU Leuven).
} 


\section{Exchange of publications * Schriftentausch * Echange de publications With compliments * Mit freundlichen Grüssen überreicht * Sincéres salutation}
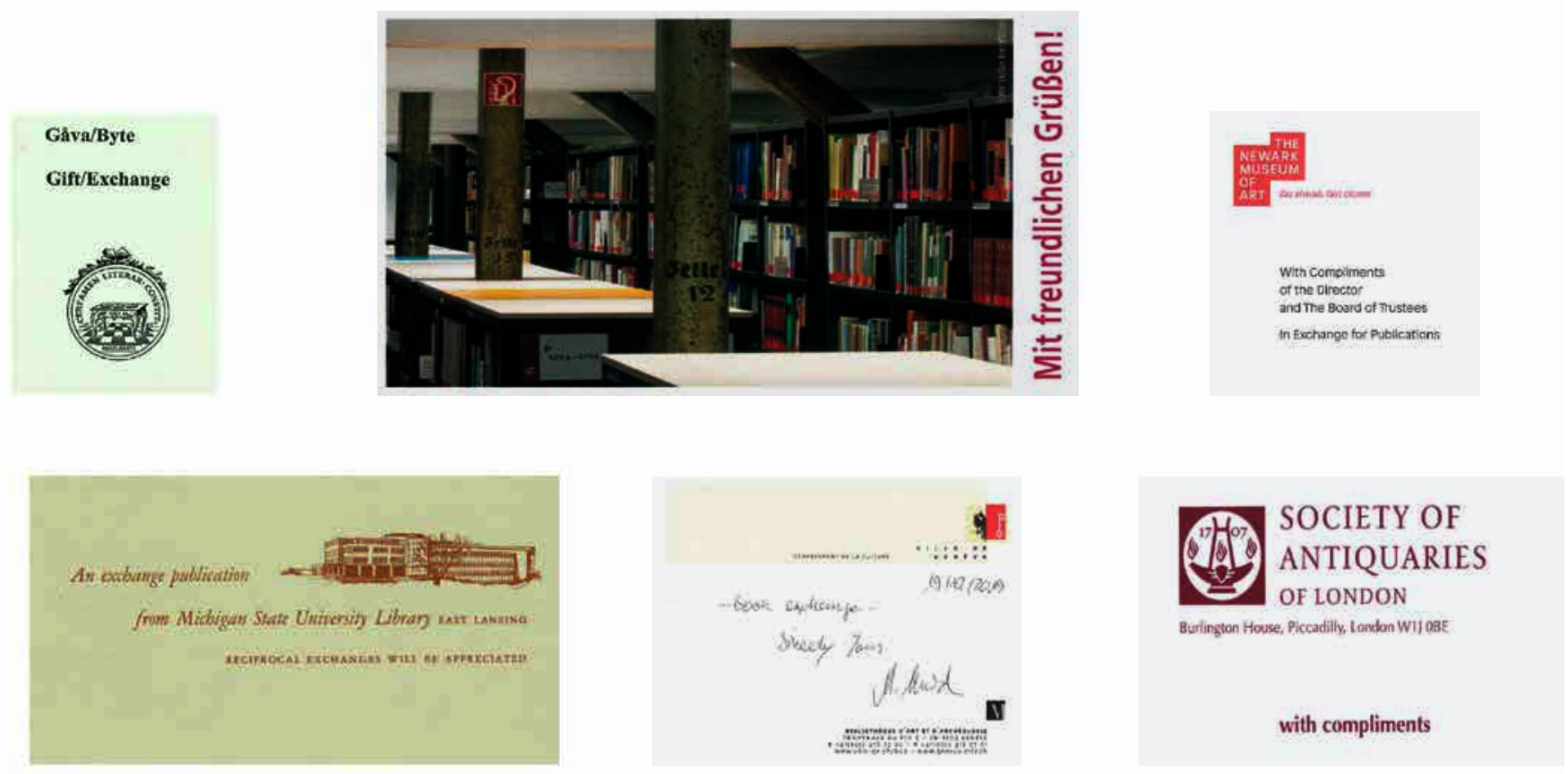

Obr. 6. Průvodní kartičky s logy institucí vkládané do zásilek s publikacemi na výměnu.

zdraví. Příznivou skutečností je, že přes tyto obtíže se podařilo zachovat roční objem výměny téměř v obvyklém rozsahu.

\section{Porovnání výměny a nákupu}

Význam mezinárodní výměny publikací názorně dokládá porovnání počtu titulů zahraničních periodik získávaných výměnou (232) vưči počtu kupovaných zahraničních titulů (83): počet titulů získaných výměnou činí téměř $3 / 4$ celkového množství. Roční rozpočet na nákup odborné literatury je vynakládán z 90\% na periodika: přesto nákup pokrývá zhruba čtvrtinu zahraničních odborných periodik. Kromě periodik dochází výměnou na 1300 titulů knižních kontinuací (nepravá periodika).

\section{Metodika a technika výměny publikací}

Tato oblast se podstatně nezměnila - nadále je nutné dodržovat zavedené postupy a evidence. Základem je pravidelná výměna periodik, rozesílání monografií individuálně nebo formou tzv. malých hromadných expedic. Stále je nutné kumulovat zásilky s ohledem na poštovné a sledovat celní zákony a poštovní podmínky. Rozesílání usnadňuje i platba poštovného převodem. Potvrzení př́ijmu probíhá převážně elektronickou poštou. Důležité je udržování aktuálního elektronického adresáře včetně e-mailových adres a individuální korespondence s výměnnými partnery, která je zásadní pro pěstování dobrých vztahů. Získané publikace jsou prvotně evidovány jednoduchým způsobem na kartách periodik a kartách výměnných partnerů, poté jsou zapsány do elektronického katalogu KNM. Dále jsou používány tyto interní pomůcky: databáze získávaných periodik, databáze získávaných knižních kontinuací a inventarizační soupisy našich publikací na výměnu.

\section{Závěr}

Mezinárodní výměna publikací Knihovny Národního muzea zůstává v období let 2011-2020 základním akvizičním zdrojem zahraniční odborné literatury jak pro Knihovnu NM, tak pro knihovny 25 odborných oddělení NM. Výměna tištěných publikací, i přes pokračující obecný trend ve vydávání odborné literatury, tj. pokles počtu periodik vydávaných $\mathrm{v}$ tištěné podobě $\mathrm{v}$ důsledku jejich přechodu na elektronický formát (bud' jako placený př́stup nebo stále častěji jako výše zmiňovaný „Open Access“), umožňuje pořízení téměř tří čtvrtin všech titulů tištěných zahraničních periodik, na 1300 titulů knižních kontinuací a knih dle našeho výběru. Důležitou roli hraje samozřejmě zájem obou stran o knižní publikace, jako jsou monografie, katalogy sbírek a katalogy výstav, které vycházejí i v současnosti v tištěné podobě. Počet výměnných partnerů Knihovny NM v letech 2011-2020 mírně poklesl, ale stále jde o velmi rozsáhlou sít’: v r. 2020 ji tvoří 792 institucí v 58 zemích světa. Nadále usilujeme o zachování vzájemně výhodných výměnných vztahů a těší nás zájem o publikace Národního muzea. Mezinárodní výměna publikací představuje významnou podporu vědecké činnosti Národního muzea. 


\section{Literatura:}

KUČEROVÁ 1998: KUČEROVÁ, Jarmila. Oddělení mezinárodní výměny publikací. In: Z pokladnice Národního muzea. 1818-1998. Praha: Národní muzeum, 1998, s. 33.

KUČEROVÁ 1999: KUČEROVÁ, Jarmila. Akvizice odborné literatury. In: Knihovna Národního muzea. Praha: Národní muzeum, 1999, s. 33-36.

KUČEROVÁ 2008: KUČEROVÁ, Jarmila. Akvizice odborné literatury v Knihovně Národního muzea. In: Knihovny současnosti 2008: Sbornik z 16. konference, konané ve dnech 16.-18. záři 2008 v Seči u Chrudimi. Brno: Sdružení knihoven ČR, 2008, s. 147-152.

KUČEROVÁ 2011: KUČEROVÁ, Jarmila. Výměna publikací Knihovny Národního muzea v letech 1990-2010. Sborník Národního muzea v Praze, řada C-Literární historie 56, 2011, č. 1-2, s. 15-19.

KUČEROVÁ 2012: KUČEROVÁ, Jarmila. Mezinárodní vztahy výměnné a jiné. Sborník Národního muzea v Praze, rada C-Literární historie 57, 2012, č. 1-2, s. 175-177.

SCHMIDT - HACKER 2017: SCHMIDT, Christian HACKER, Gerhard (ed.). Schriftentausch und digitaler Medienwandel: Eine empirische Untersuchung am Beispiel wissenschaftlicher Spezialbibliotheken. Berlin: BibSpider, 2017. Wiborada - Leipziger Arbeiten zur Bibliotheks- und Informationswissenschaft; Band 6.

SPUNAROVÁ 1974: SPUNAROVÁ, Tat'jána. Mezinárodní výměna publikací v Knihovně Národního muzea. Sborník Národního muzea v Praze, řada C-Literární historie 19, 1974, č. 1-2, s. 37-41.

SPUNAROVÁ 1976: SPUNAROVÁ, Tat'jána. Mezinárodní výměna Knihovny Národního muzea v letech 1945-1975. Sbornik Národniho muzea v Praze, řada C-Literární historie 21, 1976, č. 1, s. 55-67.

SPUNAROVÁ 1990: SPUNAROVÁ, Tatjána. Medzinárodna výmena publikácií v Knižnici Národného múzea v Prahe. Čitatel' 39, 1990, č. 11, s. 414-415.
VRCHOTKA 1956: VRCHOTKA, Jaroslav. Několik poznámek k mezinárodní výměně publikací Národního muzea v Praze. Sborník Národního muzea v Praze, rada CLiterárni historie 1, 1956, č. 2, s. 54.

VRCHOTKA 1967: VRCHOTKA, Jaroslav. Knihovna Národního musea: 1818-1892. Praha: PNP, 1967.

\section{Zákony:}

Vyhláška č. 12/1965 Sb. ministra zahraničních věcí ze dne 12. ledna 1965 o Úmluvě o výměně oficiálních publikací a vládních dokumentů mezi státy a Úmluvě o mezinárodní výměně publikací. In: Sbirka zákonů roč. 1965, částka 8. Sdělení Ministerstva zahraničních věcí č. 102/1998 Sb. o sjednání Dohody o dovozu vzdělávacích, vědeckých a kulturních materiálů. In: Sbírka zákonů roč. 1998, částka 35. Sdělení Ministerstva zahraničních věcí č. 103/1998 Sb. o sjednání Protokolu k Dohodě o dovozu vzdělávacích, vědeckých a kulturních materiálů. In: Sbírka zákonů roč. 1998, částka 35 .

\section{Elektronické zdroje:}

KUČEROVÁ 2005: KUČEROVÁ, Jarmila. Mezinárodní výměna publikací: stručný průvodce pro muzejní knihovny [online]. Praha: Národní muzeum, 2005 [cit. 22. 4. 2021]. Dostupné z: http://www.nm.cz/Oddeleni-KNM/Oddelenimezinarodni-vymeny-publikaci/Strucny-pruvodcemezinarodni-vymenou-publikaci-pro-muzejni-knihovny.

\section{Jarmila Kučerová}

Knihovna Národního muzea

oddělení mezinárodní výměny publikací

Vinohradská 1

11000 Praha 1 